\title{
Simultaneous Removal of Chromium and Lead from Water by Sorption on Iraqi Montmorillonite*
}

\author{
Mahmood M. Barbooti \\ Department of Applied Science, University of Technology, Baghdad, Iraq \\ Email: brbt2m@gmail.com
}

Received 3 March 2015; accepted 17 March 2015; published 19 March 2015

Copyright (C) 2015 by author and Scientific Research Publishing Inc.

This work is licensed under the Creative Commons Attribution International License (CC BY). http://creativecommons.org/licenses/by/4.0/

(c) (i) Open Access

\begin{abstract}
A certified clay mineral from Iraq, montmorillonite, is used for the adsorption of chromium and lead ions from water. Experimental design is utilized here to plan for the practical work and analysis of the results. Batch wise experiments are carried out to equilibrate $\mathrm{Cr}$ and $\mathrm{Pb}$ solutions (250 $\mathrm{mg} / \mathrm{L})$ individually and simultaneously with montmorillonite $(5-20 \mathrm{~g} / \mathrm{L})$ at various $\mathrm{pH}$ ranges $(2$ 7.5) for 10 - 60 minutes. The results indicate perfect fit with the model used. Chromium adsorption is sensitive to $\mathrm{pH}$ changes being high at neutral medium. Lead is almost independent of the $\mathrm{pH}$ of the solution. In nearly neutral medium, the sorption capacity of $\mathrm{Cr}$ is 21.4 and that of lead is 24.3 $\mathrm{mg} / \mathrm{g}$. The optimum conditions for $>96 \% \mathrm{Cr}$ removal are 12 - $15 \mathrm{~g}$ clay/L, 40 - 50 minutes and a $\mathrm{pH}$ of 5 - 7. For lead, almost $100 \%$ removal can be attained using $12-15 \mathrm{~g}$ clay/L, $40-50 \mathrm{~min}$. at a pH of 4 - 6 . The effects of various operating parameters are discussed. Simultaneously, the lead shows a greater tendency to sorption than chromium and a ratio of 5:4 can best represent the occupation of the active surface of the clay. The most favorable conditions for simultaneous removing of $\mathrm{Cr}, 86 \%$ and $\mathrm{Pb}, 100 \%$ may be $12.5 \mathrm{~g} / \mathrm{L}$ clay content and a $\mathrm{pH}$ of 7.5 within 30 minutes. The kinetic study of the results indicates the adsorption follow pseudo-second order kinetics in which chemical interaction is also involved. The kinetic study confirms the dependence of chromium adsorption on the $\mathrm{pH}$ of the medium being favoured at high $\mathrm{pH}$ values.
\end{abstract}

\section{Keywords}

Lead, Chromium, Adsorption, Water Heavy Metals Removal, Montmorillonite

${ }^{*}$ Partly presented at the Mid-Atlantic Regional Meeting of the American Chemical Society, MARM 2011, Maryland University, 21-24 May 2011. 


\section{Introduction}

Chromium and lead are among the toxic heavy metals in the environment. Lead contamination comes mainly from lead in paint, gasoline, water distribution systems, food, and lead used in hobby activities. Lead exposure attributable to automobile air emissions was a major exposure source prior to 1976. The use of leaded gasoline declined in developed countries but was still used in other countries. Water is contaminated in the distribution networks and the possibility of contamination will increase with the decrease of $\mathrm{pH}$ of water. When lead-paint is deteriorated, the risks of lead poisoning increase to children because of abrasion into dust. Food may also be contaminated by the lead through the soil contaminated with lead or the use of insecticides that contain lead [1]. Lead exposure may cause renal disease, irreversible neurologic damage and cardiovascular effects. Lead in blood increases dramatically in the people who work in crowded intersections when leaded gasoline is still in use. Lead will move to living bodies by grazing and food chains. A recent study indicates that the wire and cable manufacturing and the rubber and plastic industry are the largest reported users of lead compounds [2].

Many techniques were utilized for the removal of lead from aqueous medium like emulsion liquid membrane [3], adsorption on bagasse ash [4], adsorption on clay [5], biosurfactant, [6], and ion-exchange with faujasite tuff [7].

Several materials and methods were used for the removal of chromium like precipitation [8] [9], ion exchange [10] [11], and wastewater sludge [12]. Adsorption was widely used for the removal of chromium using waste materials [13]-[16]. Infiltration in soil, and uptake by wetland plants, also accounted for some removal practices [17].

The main human activities that increase the concentrations of chromium are steel, leather, textile manufacturing and electro painting. These applications will mainly increase concentrations of chromium in water. Through coal combustion chromium will also end up in air and through waste disposal chromium will end up in soils. Most of the chromium in air will eventually settle and end up in waters or soils. Chromium in soils strongly attaches to soil particles and as a result it will not move towards groundwater. In water, chromium will absorb on sediment and become immobile. Only a small part of the chromium that ends up in water will eventually dissolve.

Crops contain systems that arrange the chromium-uptake to be low enough not to cause any harm. But when the amount of chromium in the soil rises, this can still lead to higher concentrations in crops. Acidification of soil can also influence chromium uptake by crops. Plants usually absorb only chromium (III). This may be the essential kind of chromium, but when concentrations exceed a certain value, negative effects can still occur.

Chromium (III) is an essential nutrient for humans and shortages may cause heart conditions, disruptions of metabolisms and diabetes. But the uptake of too much chromium (III) can cause health effects as well, for instance skin rashes. Chromium (VI) exposure may come from steel and textile industries as well as from smoking. The health hazards associated with exposure to chromium are dependent on its oxidation state. The hexavalent form, $\mathrm{Cr}(\mathrm{VI})$, is toxic and has adverse effects on the skin like ulcerations, dermatitis, and allergic skin reactions. Inhalation of $\mathrm{Cr}(\mathrm{VI})$ compounds can result in ulceration and perforation of the mucous membranes of the nasal septum, irritation of the pharynx and larynx, asthmatic bronchitis, bronchospasms and edema. Respiratory symptoms may include coughing and wheezing, shortness of breath, and nasal itch. According to National Toxicology Program, NTP, there is sufficient evidence for carcinogenicity in experimental animals for some hexavalent chromium compounds [18].

For this reason, it is essential to remove lead and chromium from water and other environmental elements. Oswald, et al. [19] reviewed the methods of chromium removal and concluded that adsorption offered significant advantages like low cost, availability, profitability, ease of operation and efficiency, in comparison with conventional methods (such as membrane filtration or ion exchange) especially from economical and environmental points of view. Miretzky, et al. [20] used dead macrophytes for the removal of heavy metal ions like $\mathrm{Cd}^{2+}, \mathrm{Ni}^{2+}, \mathrm{Cu}^{2+}, \mathrm{Zn}^{2+}$ and $\mathrm{Pb}^{2+}$ from water. Lead was the most efficiently removed from the solution. Carmona, et al. [21] employed experimental design for the evaluation of the performance of biosorption of chromium for two levels of the operating parameters for a wide range of metal ion concentration. Barrado, et al. [22] attained optimal heavy metal removal ( $>99 \%$ ) by precipitation as magnetic ferrites by treating wastewater with iron(II) sulfate for 2 hours at $50^{\circ} \mathrm{C}$ and $\mathrm{pH} 10$ in the presence of in a ratio [Fe(II)]/[total metal] of 15. Gaikwad, et al. [23] employed factorial design analysis for the study of copper removal from acid mine drainage by ion exchange.

The focus of the present work will be on the utilization of a certified Iraqi clay mineral, montmorillonite for the removal of chromium and lead individually and simultaneously from water and the use of Experimental Design in the planning of experiments and the analysis of the results to achieve the most favorable conditions. 


\section{Materials and Methods}

\subsection{Apparatus}

Lead and chromium concentrations were measured with induced coupled plasma optical emission spectrometry on ICP-MS Thermo X-Series II, Thermo-Electron, San Hose, CT).

\subsection{Materials and Reagents}

Stock solutions of lead and chromium $(5000 \mathrm{mg} / \mathrm{L}$ were prepared from analytical grade reagents in $1 \%$ nitric acid. Nanopure water (Barnstead NanoPureII, Dubuque, IA) was used throughout the study. The clay mineral used was a high quality Montmorillonite claystone of Wadi Bashira certified clay obtained from the Iraqi Geological Survey and with the following characteristics: Monmorillonite (77.0\%); Loss on Ignition =11.0; Organic Matter $=0.47$; CEC $=0.7659 \mathrm{eq} / \mathrm{g}$.

Buffer solutions were prepared from Pipes which is the common name for piperazine-N, N'-bis (2-ethanesulfonic acid). A stock solution of $10 \mathrm{mM}$ concentration was prepared from which the working $\mathrm{pH}$ buffers were prepared by simple adjustment of the main buffer with drops of $0.1 \mathrm{M} \mathrm{HCl}$ and $0.1 \mathrm{M} \mathrm{NaOH}$.

\subsection{Adsorption Studies}

In 15-mL centrifuge tubes, a weighed amount of montmorillonite was placed together with $0.1 \mathrm{~mL}$ of $1.0 \mathrm{M} \mathrm{KCl}$ and $0.4 \mathrm{~mL}$ of the metal stock solutions. The final dilution was made to $10 \mathrm{~mL}$ with the pre-prepared buffer solution. All the sample solutions were prepared in duplicate. The sampling tubes were placed on a rotary shaker and run at a speed of $250 \mathrm{rpm}$ for the predetermined times at the lab temperature which ranged between $19^{\circ} \mathrm{C}$ $21^{\circ} \mathrm{C}$. After equilibration, the samples were centrifuged at $3000 \mathrm{rpm}$ for $10 \mathrm{mins}$ to aid solid separation. The solutions were filtered through $0.22 \mu \mathrm{m}$ syringe filters into plastic vials and kept at $4^{\circ} \mathrm{C}$ for metal analysis.

The same procedure was repeated for solutions containing both chromium (III) and lead at a starting concentration of $200 \mathrm{mg} / \mathrm{L}$. Aliquots of the filtered solutions were diluted with $1 \% \mathrm{HNO}_{3}$ solution and kept for analysis by ICP MS.

\section{Design of Experiments}

The central composite design [24] was used in this work to allow studying the effects of three main parameters at five levels: equilibration time, 10 - 60 minutes; pH, 2 - 7.5 and clay content: 5 - 20 g/L. Jump 8 program was also employed for the analysis of the adsorption data. Five levels of each parameter were used and the coded and real values of the variables are listed in Table 1.

\section{Results and Discussion}

The heavy metal sorption capacity, $C_{s}$ (mg/L or mmol/kg), was calculated by Equation (1):

$$
C_{s}=\left(C_{\text {cont }}-C_{\text {eq }}\right) \times \frac{V}{m}
$$

where, $C_{\text {cont }}$ and $C_{\text {eq }}(\mathrm{mg} / \mathrm{L})$ are the control and equilibrium aqueous metal concentrations, respectively, $V(\mathrm{~L})$ is the volume of solution, and $m(\mathrm{~g})$ is the mass of the clay. However, the initial concentrations of the $\mathrm{Pb}$ and $\mathrm{Cr}$ were not considered for the estimation of the amount adsorbed to avoid any possible loss of metal ions by adsorption onto the walls of the container.

The percent of metals sorbed to clay is calculated according to Equation (2).

$$
\text { Ads } \%=\frac{C_{\text {cont }}-C_{\text {eq }}}{C_{\text {cont }}} \times 100=\frac{C_{s}}{C_{\text {cont }}} \times 100 .
$$

The Ads\% and $C_{s}$ values where then used in the statistical treatment of the results to evaluate the effects of operating parameters on the response.

\subsection{Chromium Adsorption}

The data of the chromium adsorption capacity were analyzed with the JUMP 8 program to predict the response 
Table 1. Coded and real variable of the operating parameters used in the experiments.

\begin{tabular}{|c|c|c|c|c|}
\hline Run No. & Pattern & Time, min & Clay, g/L & $\mathrm{pH}$ \\
\hline 1 & -- & 20 & 8.0 & 3.11 \\
\hline 2 & --+ & 20 & 8.0 & 6.39 \\
\hline 3 & -+- & 20 & 16.96 & 3.11 \\
\hline 4 & -++ & 20 & 16.96 & 6.39 \\
\hline 5 & +-- & 50 & 8.0 & 3.11 \\
\hline 6 & +-+ & 50 & 8.0 & 6.39 \\
\hline 7 & ++- & 50 & 16.96 & 3.11 \\
\hline 8 & +++ & 50 & 16.96 & 6.39 \\
\hline 9 & A00 & 10 & 12.5 & 4.75 \\
\hline 10 & A00 & 60. & 12.5 & 4.75 \\
\hline 11 & $0 \mathrm{~A} 0$ & 35 & 5 & 4.75 \\
\hline 12 & $0 \mathrm{~A} 0$ & 35 & 20.0 & 4.75 \\
\hline 13 & $00 \mathrm{~A}$ & 35 & 12.5 & 1.992 \\
\hline 14 & $00 \mathrm{~A}$ & 35 & 12.5 & 7.5 \\
\hline 15 & 000 & 35 & 12.5 & 4.75 \\
\hline 16 & 000 & 35 & 12.5 & 4.75 \\
\hline 17 & 000 & 35 & 12.5 & 4.75 \\
\hline 18 & 000 & 35 & 12.5 & 4.75 \\
\hline 19 & 000 & 35 & 12.5 & 4.75 \\
\hline 20 & 000 & 35 & 12.5 & 4.75 \\
\hline
\end{tabular}

values as a means for the assessment of the chosen model. The actual $C_{s}$ values were correlated with the predicted values and the plot is shown in Figure 1 . The correlation appears significant with a $R^{2}$ value of 0.89 and a $P$ value of 0.001 and RMSE value of 2.0311 .

By ignoring the nonsignificant terms, the equation of predicting $C_{s}$ values can be as follows:

$$
\mathrm{Cr}_{s}=25.98+0.0196 t-0.104 \text { Clay }+0.7827 \mathrm{pH}+0.0307(t \times \mathrm{pH})-0.097 \mathrm{pH}^{2}
$$

Figure 2 shows the effect of $\mathrm{pH}$ on the chromium adsorption capacity on $12.5 \mathrm{~g}$ montmorillonite/L at fixed Equilibrium Times. For a short equilibration time interval, $10 \mathrm{~min}$, the maximum sorption capacity of not more than $16 \mathrm{mg} / \mathrm{g}$ was obtained at $12.5 \mathrm{~g} / \mathrm{L}$. The highest $C_{s}$ could be obtained with 50 minutes equilibrium time for the same clay content. Further time interval does not help to improve the $C_{s}$ further. Similarly, the $\mathrm{Cr}$ - clay interaction was the highest, $21 \mathrm{mg} / \mathrm{g}$, after 50 minutes of equilibrium at nearly neutral medium, $\mathrm{pH}=6.39$. The low $\mathrm{pH}$ medium is not favorable for chromium sorption on montmorillonite due to the expected desorption and high solubility of chromium species. Thus, chromium can be best adsorbed on montmorillonite at neutral medium for a clay content of $12.5 \mathrm{~g} / \mathrm{L}$ of the clay. This is in agreement with the published reports [Carmona, et al, 2005] which revealed the impact of $\mathrm{pH}$ as the most significant effect regarding $\mathrm{Cr}^{3+}$ uptake on the biosorbent (Sargassum sp.). Also, Pandey, et al. [25] reported that the adsorption of $\mathrm{Cr}(\mathrm{VI})$ decrease with $\mathrm{pH}$ increase. Thus, the chemistry of $\mathrm{Cr}$ is the determining factor in the adsorption and not the sorbent properties. Wehrli, et al. [26] attributed the dependence of $\mathrm{Cr}$ adsorption on the $\mathrm{pH}$ to the fact that the protons are involved in the kinetic equation of $\mathrm{Cr}$ adsorption on aluminum hydroxide.

Maximum $C_{s}$, of chromium ( $25 \mathrm{mg} / \mathrm{g}$ ) could be obtained with relatively low clay content of $8 \mathrm{~g} / \mathrm{L}$ at a pH of 5 . The sorption capacity is inversely proportional with the clay content. However, a clay content of $8 \mathrm{~g} / \mathrm{L}$ gave identical $C_{s}$ to the $5 \mathrm{~g} / \mathrm{L}$ over a wide range of equilibrium time of 15 - 50 minutes. Longer contact time may not be recommended at slightly acidic solutions as a slight decrease of $C_{s}$ could occur. Although low clay content may be in favor of increasing the quotient of adsorbed $\mathrm{Cr}$ on the clay content, the low clay content was not enough to give the required adsorption. It seems that there exists a compromise between clay content and the other conditions where the best $\mathrm{Cr}$ removal could be obtained with $8 \mathrm{~g} / \mathrm{L}$.

The $C_{s}$ of chromium on montmorillonite is greatly affected by $\mathrm{pH}$ of the solution regardless of the clay content. The best performance could be noticed at a clay content of 12.5 at a nearly neutral $\mathrm{pH}$ (6.4). At low $\mathrm{pH}$ the long 


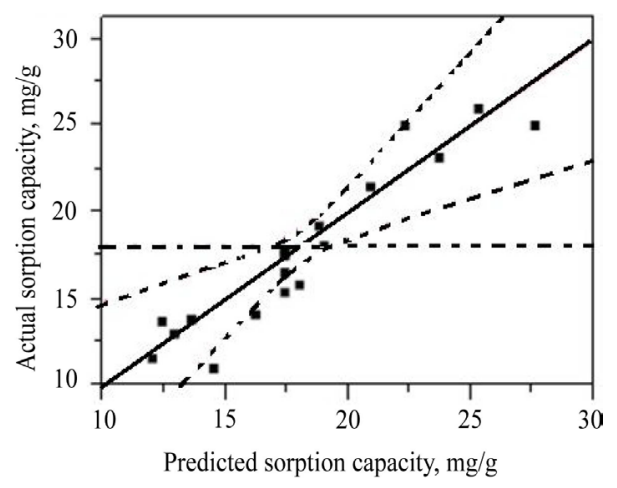

Figure 1. Correlation of predicted chromium adsorption capacity values with the actual values.

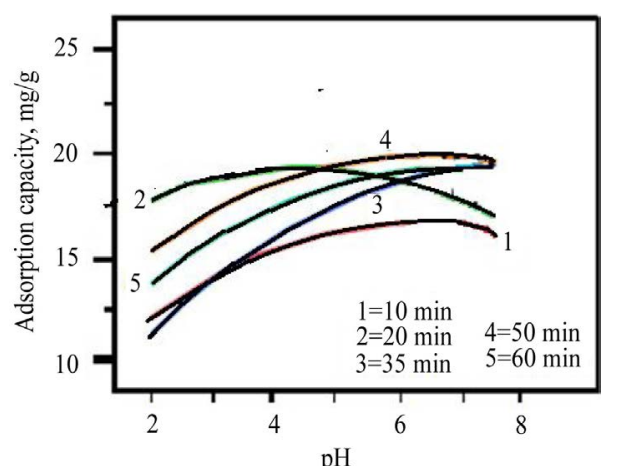

Figure 2. Effect of $\mathrm{pH}$ on the chromium adsorption capacity on $12.5 \mathrm{~g} / \mathrm{L}$ of montmorillonite using various equilibrium times.

equilibrium time resulted in desorption of $\mathrm{Cr}$ from the clay surface. Meanwhile the long equilibrium improved the Cs for moderate acidic and neutral media. At a pH of 6.4, the $C_{s}$ gradually increased with time between 16 and 22 $\mathrm{mg} / \mathrm{g}$ within 40 minutes showing the effectiveness of the neutral medium in holding $\mathrm{Cr}$ on montmorillonite.

\subsection{Chromium Adsorption Efficiency}

Both $\mathrm{pH}$ and the clay content have significant impacts on adsorption efficiency of chromium on montmorillonite. After careful evaluation the following relation could be obtained for the Cr sorption efficiency:

$$
\text { CrAds } \%=34.57+0.114 t+0.243 \text { Clay }+3.813 \mathrm{pH}-0.66 \mathrm{pH}^{2}+0.091(t \times \mathrm{pH})
$$

Regardless of the clay content and $\mathrm{pH}$ of the solution, equilibrium time of not less than 35 minutes is necessary to attain appreciable sorption. Figure 3(a) indicates that at least $13 \mathrm{~g}$ monmorillonite / $\mathrm{L}$ gave the highest $\mathrm{Cr}$ removal in slightly acidic medium $(\mathrm{pH}=4.75)$. However, Figure $3(\mathrm{~b})$ indicates that low $\mathrm{pH}$ values are not in favor of good sorption performance of $\mathrm{Cr}$.

For the $250 \mathrm{mg} / \mathrm{L}$ concentration used, 60 minutes could only be adequate to cause $80 \%$ of the chromium removal on $12.5 \mathrm{~g} / \mathrm{L}$. With $16.7 \mathrm{~g} / \mathrm{L}$, only 40 minutes at a $\mathrm{pH}$ of 6.4 were enough to bring about total removal of chromium. Thus, a saturation value of $17 \mathrm{mg} / \mathrm{g}$ characterizes the process. At a $\mathrm{pH}$ value of 7.5 , the saturation value increased to $17.85 \mathrm{mg} / \mathrm{g}$ after 40 minutes.

\section{Adsorption Capacity of Lead on Montmorillonite}

From the statistical treatment of the experimental results, it appears that all the operating parameters are affecting the adsorption capacity of lead on montmorillonite. However, the monmorillonite content is the most significant parameter in the process and the $\mathrm{pH}$ was the least significant. Excellent correlation exists between the predicted 
adsorption capacity values and the real experimental response $\left(\mathrm{R}^{2}=0.987\right)$. The lead $C_{s}$ can be best decribed by Equation (5):

$$
\mathrm{PbC}_{s}=42.17+0.356 t-4.1 \text { Clay }+1.5 \mathrm{pH}-0.011(\text { Clay } \times t)+0.133 \text { Clay }^{2}-0.09(\mathrm{pH} \times \text { Clay })+0.0353 \mathrm{pH}^{2}
$$

The response surface of the lead $C_{s}$ is shown in Figure 4. The maximum $C_{s}$ of lead $(21 \mathrm{mg} / \mathrm{g})$ occurs when the medium is nearly neutral (6.4) after 35 minutes. Figure 5 shows the effect of equilibration time on lead adsorption capacity at $\mathrm{pH}=4.75$ and various clay contents. It is clear that even in slightly acidic medium lead is more efficiently sorbed on montmorillonite than chromium and increase with the increase of contact time specially with low clay content. The removal of lead was best done in acidic media: $\mathrm{pH} 3.0$ using low cost bagasse [4] and $\mathrm{pH}$ 1.4 for lead removal from storage battery industry wastewater of an initial lead concentration of $4.2 \mathrm{mg} / \mathrm{L}$ using emulsion liquid membrane technique [4].

Thus, the adsorption capacity of Iraqi montmorillonite for lead $(24.28 \mathrm{mg} / \mathrm{g}, 0.1173 \mathrm{nM} / \mathrm{g})$ is comparable to those reported for Saudi clay (30 mg/g, $0.147 \mathrm{mM} / \mathrm{g}$ ) [5] and coconut shell carbon (26.50 $\mathrm{mg} \mathrm{g}^{-1}$ ) [27].

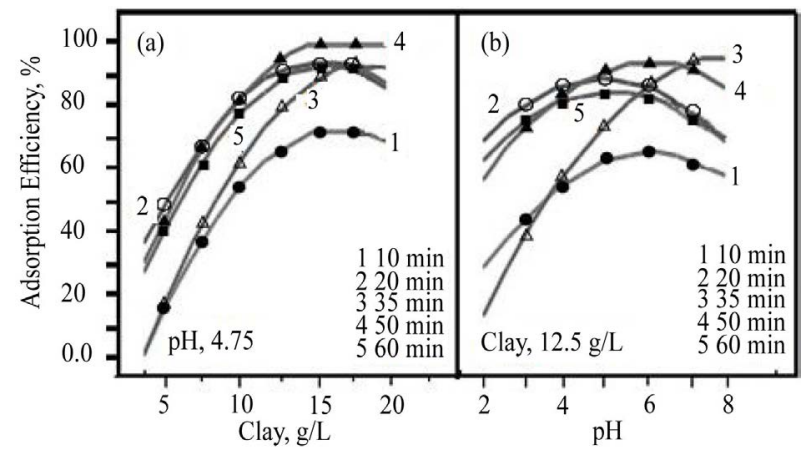

Figure 3. Effects of clay contents and $\mathrm{pH}$ on chromium adsorption efficiency at various equilibrium times..

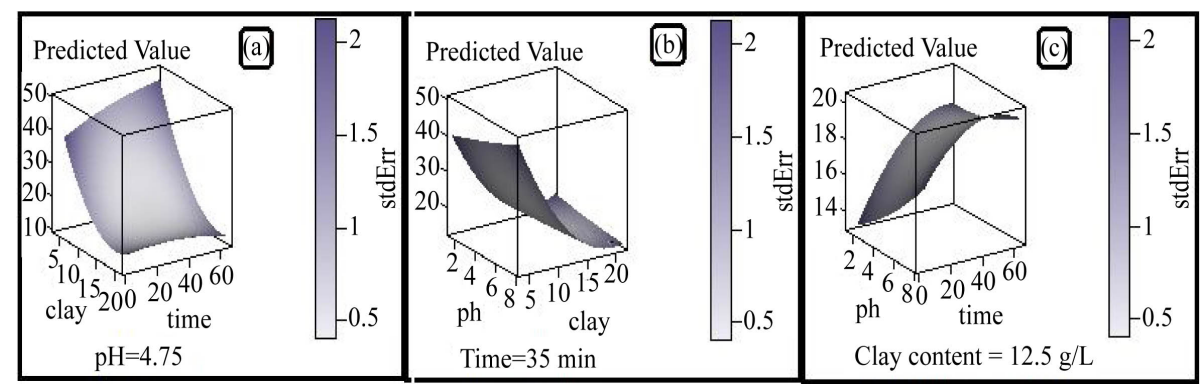

Figure 4. The response surface of lead adsorption capacity.

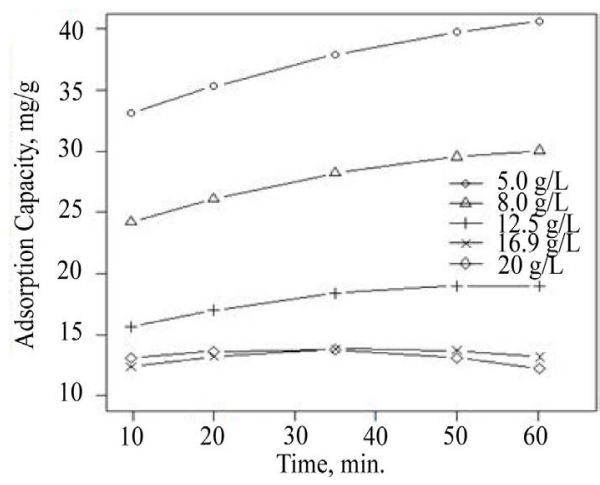

Figure 5. Effect of equilibration time on lead adsorption capacity at $\mathrm{pH}=4.75$ and various clay contents. 
The effect of $\mathrm{pH}$ is not significant on lead $C_{\mathrm{s}}$ as we can reach considerable value at low $\mathrm{pH}$ by longer contact time. It was found that a clay content of $12.5 \mathrm{~g} / \mathrm{L}$ gave $18.5 \mathrm{mg} / \mathrm{g}$ at a $\mathrm{pH}$ of 2.0 after 50 minutes and at $\mathrm{pH}$ of 7.5 after 20 minutes. With the neutral environment, $\mathrm{pH}=7.5$, the contact time have minor effect on the sorption capacity.

\section{Lead Adsorption Efficiency}

The overall relationship of the adsorption efficiency with the operatinng parameters can be expressed as in Equation (6):

$$
\text { PbAds } \%=62.38+0.314 t+0.097 \text { Clay }+1.372 \mathrm{pH}+0.0117(t \times \mathrm{pH})-0.043(\text { Clay } \times \mathrm{pH})+0.2540 \mathrm{pH}^{2}
$$

Figure 6 shows the dependence of the sorption efficiency of $\mathrm{Pb}$ on montmorillonite on the clay content at a $\mathrm{pH}$ value of 4.75 and various equilibration intervals. The process is relatively slow and an equilibrium time of 10 minutes seems inadequate to give appreciable adsorption even with high clay content. Meanwhile, a clay content of 13 - $15 \mathrm{~g} / \mathrm{L}$ gave maximum adsorption (94\%) after 50 minutes. The adsorption efficiency undergoes slight increase with the increase of $\mathrm{pH}$ of the medium and the maximum can be attained beyond a pH of 6 after 40 minutes of equilibrium. Low clay content of $5 \mathrm{~g} / \mathrm{L}$ appeared adequate to give appreciable Ads\% ( 90\%) with long contact time (60 min.). The best case occurred with 16 - $17 \mathrm{~g} / \mathrm{L}$ clay content, where a complete sorption of lead on montmorillonite occurred after 50 minutes. Thus, the best operating conditions for the lead sorption are: $\mathrm{pH}=6.4$, time $=$ $40 \mathrm{~min}$. and clay content $16-17 \mathrm{~g} / \mathrm{L}$.

The response surface between $\mathrm{pH}$ and clay content after 35 minutes indicated a steady state of adsorption above a pH of 6.5 and clay content in the range of $10-15 \mathrm{~g} / \mathrm{L}$ (Figure 7).

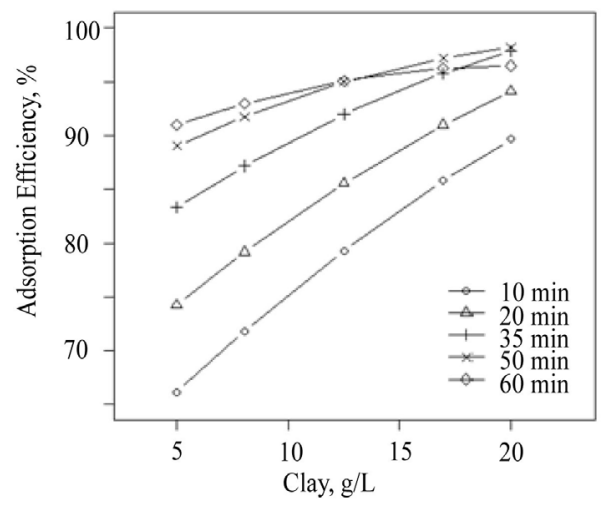

Figure 6. Effects of clay contents on lead adsorption efficiency at a $\mathrm{pH}$ of 4.75 and various equilibration times.

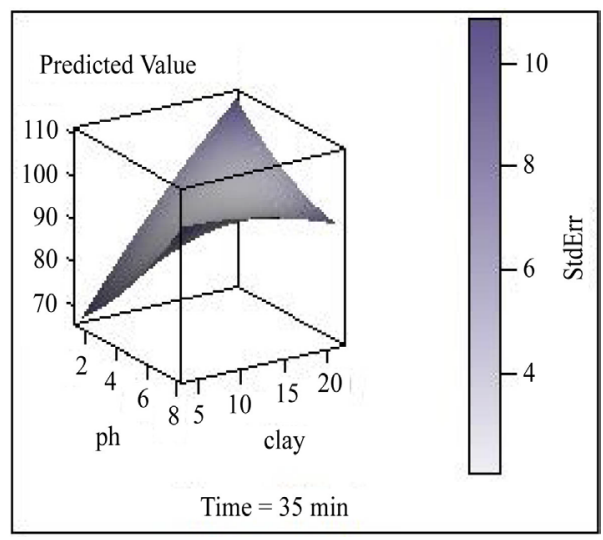

Figure 7. The response surface of lead adsorption efficiency for $\mathrm{pH}$ and clay content. 


\section{Simultaneous Adsorption of $\mathrm{Pb}$ and $\mathrm{Cr}$ by Montmorillonite}

\subsection{Sorption Capacity, $C_{S}$}

When the two metal ions, $\mathrm{Cr}$ and $\mathrm{Pb}$ were present together, appreciable reduction in their concentration could be observed. Figure 8 and Figure 9 show the correlation of the actual $C_{s}$ values with those predicted with the applied model for both $\mathrm{Cr}$ and $\mathrm{Pb}$. For $\mathrm{Cr}$, the correlation coefficient, $\mathrm{R}^{2}$ was 0.83, RMSE $=1.262$ and $\mathrm{p}=0.0069$.

For $\mathrm{Pb}$, the correlation coefficient, $\mathrm{R}^{2}$ was 0.92 , $\mathrm{RMSE}=1.1534$ and $\mathrm{p}=0.0002$. Thus, the model fits better for lead than chromium and the montmorillonite particles can adsorb more lead ions than chromium. The clay content represents the denominator in the calculation of $C_{s}$ and thus, its effect is negative on the adsorption capacity. The terms and their significance to the process are shown in Table 2 for Cr. The time and $\mathrm{pH}$ are the most significant parameters in the sorption of $\mathrm{Cr}$ on montmorillonite in addition to their combined action.

For $\mathrm{Pb}$, the terms and their significance to the process are shown in Table 3. The statistical analysis indicated the significance of clay content and the $\mathrm{pH}$ on the lead adsorption. Also the combined actions of clay with $\mathrm{pH}$ and $\mathrm{pH}$ with time were found to be significant in the estimation of adsorption capacity.

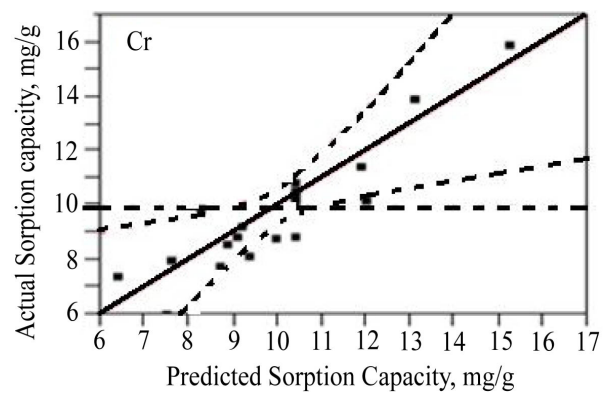

Figure 8. The correlation of actual $C_{s}$ Values with the predicted values for $\mathrm{Cr}$ in the presence of $\mathrm{Pb}$.

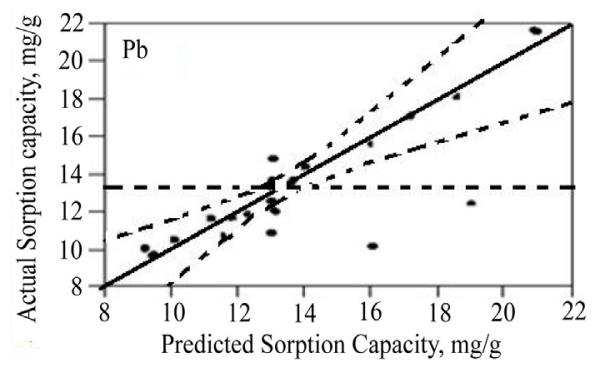

Figure 9. The correlation of actual $C_{s}$ values with the predicted values for $\mathrm{Pb}$ in the presence of $\mathrm{Cr}$.

Table 2. Statistical analysis of the chromium adsorption data.

\begin{tabular}{|c|c|c|c|c|}
\hline Term & Estimate & Std Error & Prob $>|t|$ & Significance \\
\hline Intercept & 5.407903 & 1.671581 & 0.0089 & $S$ \\
\hline Time & 0.059624 & 0.022766 & 0.0256 & S \\
\hline Clay & -0.15817 & 0.076552 & 0.0657 & NS \\
\hline $\mathrm{pH}$ & 1.022132 & 0.208236 & 0.0006 & S \\
\hline (Time)*(Clay) & -0.0115 & 0.00667 & 0.1155 & NS \\
\hline (Time)*(pH) & 0.051526 & 0.018138 & 0.0175 & S \\
\hline (Clay)*(pH) & -0.01904 & 0.061002 & 0.7614 & NS \\
\hline (Time)*(Time) & $-8.31 \mathrm{E}-06$ & 0.001477 & 0.9956 & NS \\
\hline (Clay)*(Clay) & -0.02858 & 0.016698 & 0.1177 & NS \\
\hline$(\mathrm{pH}) *(\mathrm{pH})$ & -0.01084 & 0.123616 & 0.9319 & NS \\
\hline
\end{tabular}


Table 3. Statistical analysis of the lead adsorptiondata.

\begin{tabular}{ccccc}
\hline Term & Estimate & Std Error & Prob $>|\mathbf{t}|$ & Significance \\
\hline Intercept & 15.54749 & 8.746228 & 0.1058 & NS \\
Time & 0.225313 & 0.119116 & 0.0878 & NS \\
Clay & 3.011732 & 0.400543 & $<0.0001$ & $\mathrm{~S}$ \\
$\mathrm{pH}$ & 4.288662 & 1.089557 & 0.0028 & $\mathrm{~S}$ \\
$(\text { Time })^{*}(\mathrm{Clay})$ & 0.009235 & 0.034897 & 0.7967 & $\mathrm{NS}$ \\
$($ Time $*(\mathrm{pH})$ & 0.223185 & 0.094903 & 0.0405 & $\mathrm{~S}$ \\
$($ Clay $*(\mathrm{pH})$ & -0.73745 & 0.31918 & 0.0435 & $\mathrm{~S}$ \\
$($ Time $*($ Time $)$ & -0.00323 & 0.007729 & 0.6846 & NS \\
$($ Clay $*(\mathrm{Clay})$ & -0.17957 & 0.087369 & 0.0669 & NS \\
$(\mathrm{pH}) *(\mathrm{pH})$ & 0.431354 & 0.646797 & 0.5199 & NS \\
\hline
\end{tabular}

The effect of clay content on the sorption capacity of chromium and lead in the presence of each other at a slightly acidic medium, $\mathrm{pH}=4.75$ and various contact times was evaluated. Regardless of the contact time the $C_{s}$ of $\mathrm{Pb}$ decreased almost linearly with the clay content. For chromium moderate contact times (20 - 40 minutes) showed a maximum $C_{s}$ with 10 - $13 \mathrm{~g} / \mathrm{L}$ clay content. With long contact time, $60 \mathrm{~min}$, the $C_{s}$ of chromium showed a rapid drop with the increase of clay content. Clear improvement in the chromium $C_{s}$ could be noticed with the increase of $\mathrm{pH}$. However, at a clay content of $12.5 \mathrm{~g} / \mathrm{L}$ a steady level of $C_{s}(10 \mathrm{mg} / \mathrm{g})$ was obtained over the whole pH range employed.

The effect of contact time on the sorption Efficiency of chromium and lead on $12.5 \mathrm{~g} / \mathrm{L}$ of montmorillonite at various $\mathrm{pH}$ values was also studied. The $\mathrm{pH}$ of the medium is a determining factor in a successful chromium sorption on montmorillonite. A slight increase of Cr Ads\% with time and almost constant level, 71\% - 75\%, of Cr sorption could be obtained at nearly neutral medium, $\mathrm{pH}, 6.39$, regardless of the contact time. Lead could be entirely removed from solution by sorption on $12.5 \mathrm{~g} / \mathrm{L}$ of montmorillonite at a $\mathrm{pH}$ value of 6.39 after 60 minutes and after 35 minutes at a $\mathrm{pH}$ of 7.5. However, improved $\mathrm{Cr}$ adsortion, 86\%, can be obtained at a pH value of 7.5 within 30 minutes. Thus, the most favorable conditions for simultaneous $\mathrm{Cr}$ and $\mathrm{Pb}$ may be $12.5 \mathrm{~g} / \mathrm{L}$ clay contaent and a $\mathrm{pH}$ of 7.5 within 30 minutes.

\subsection{Adsorption Isotherm}

The plot of Log $C_{s}$ against $\log C_{\mathbf{e q}}$ is given in Figure 10. The plot indicates a linear correlation over the clay content range of $5-17 \mathrm{~g} / \mathrm{L}$ controls the adsorption of lead on montmorillonite with a correlation coefficient, $R^{2}$, of 0.9453:

$$
\log C_{s}=0.75+0.517 \log C_{\text {eq }}
$$

$C_{s}$ values were used to calculate sorption coefficients as defined by

$$
K_{d}=\frac{C_{s}}{C_{\text {eq }}(\mathrm{CEC})}
$$

where $K_{d}$ (L/equiv) is the overall sorption coefficient, $C_{e q}(\mathrm{mg} / \mathrm{L})$ is the equilibrium aqueous $\mathrm{Pb}$ concentration, and CEC (meq/g) is the cation exchange capacity of the clay. The adsorbed $\mathrm{Pb}$ on solid was plotted against the equilibrium concentration in solution as in Figure 11. The overall adsorption coefficient was calculated by dividing the slop of the plot, $1.025 \mathrm{~L} / \mathrm{g}$, by the cation exchange capacity, CEC, of montmorillonite, $0.766 \mathrm{meq} / \mathrm{g}$. A value of $1.338 \mathrm{~L} / \mathrm{meq}$ was obtained for $250 \mathrm{mg} / \mathrm{L} \mathrm{Pb}$ concentration level which is comparable with the value of the $K_{d}$ values for sodium montmorillonite for relatively high iron concentration levels [28].

\section{Sorption Kinetics}

Kinetics of metal sorption governs the rate, which determines the residence time, and it is one of the important characteristics defining the efficiency of an adsorbent [29]. Sorption kinetics can be controlled by several independent processes that could act in series or in parallel, such as bulk diffusion, external mass transfer (film diffusion), chemical reaction (chemisorption) and intra-particle diffusion [30]. The pseudo-second order kinetic 


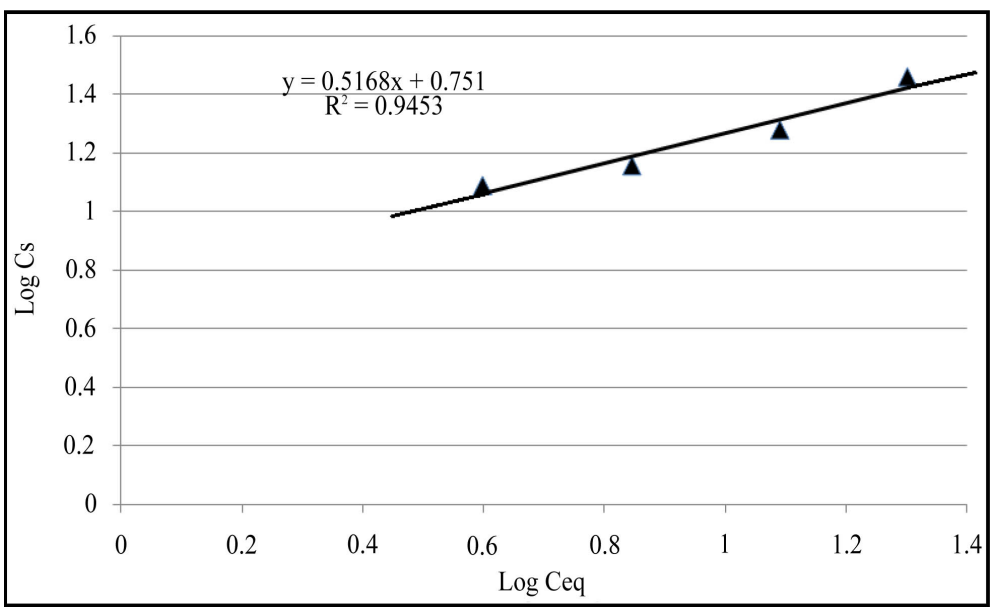

Figure 10. Adsorption isotherm of lead on montmorillonite..

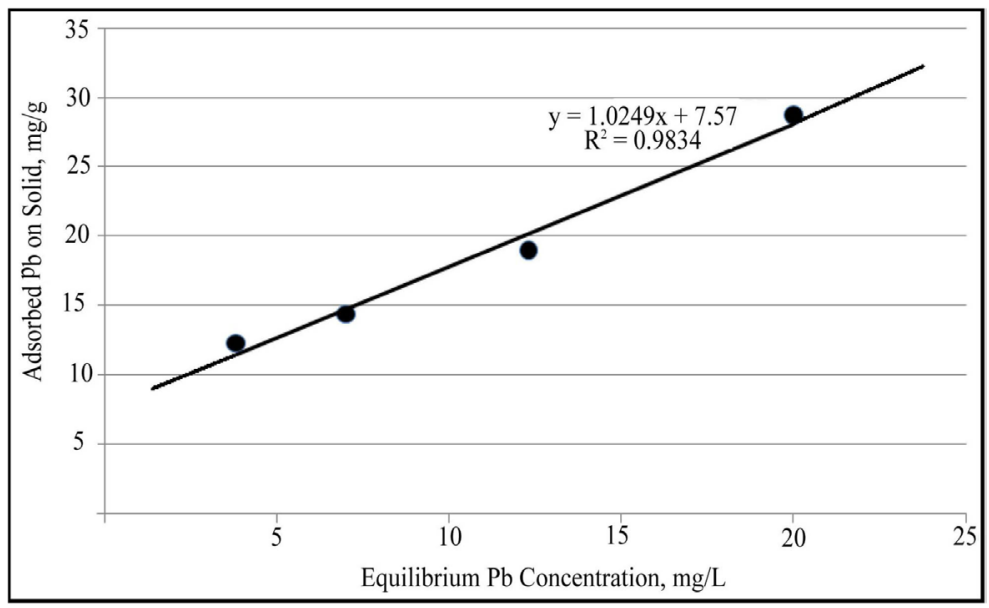

Figure 11. Adsorption coefficient of lead on montmorillonite.

equation, developed by Ho et al., [30]:

$$
\frac{t}{C_{s}}=\frac{1}{k_{2}\left(C_{\text {seq }}\right) 2}+\frac{t}{C_{\text {seq }}}
$$

Or

$$
t / C_{s}=1 /\left[k_{2}\left(C_{s(\mathrm{eq})}\right)^{2}\right]+t /\left(C_{s(\mathrm{eq})}\right)
$$

where $k_{2}$ is the equilibrium rate constant for the Pseudo-second order adsorption $\left(\mathrm{g} \cdot \mathrm{mg}^{-1} \cdot \mathrm{min}^{-1}\right)$ and can be evaluated from the plot of $t / C_{s}$ vs time. This model is based on the assumption that the rate limiting step may be a chemical adsorption involving valence forces through sharing or exchange of electrons between the adsorbent ans the adsorbate. Demirbas, et al., [31] applied this kinetic model successfully for the adsorption of metals.

Figure 12 shows the lead adsorption kinetic plots following pseudo second order model at $\mathrm{pH}$ values 3 - 7.5. Figure 13 shows the chromium (III) adsorption kinetic plots following pseudo second order model at pH values of 3 - 7.5. The plots indicated reasonable fit with the pseudo second order rate equation with correlation coefficient values, $R^{2}$, values of 0.947 to 0.9967 . The equilibrium adsorption capacity, $C_{s}$, was calculated from the slope of the plot and adsorption constant was calculated from the intercept of the linear plots. The results are presented in Table 4. From the table, the effect of $\mathrm{pH}$ on the equilibrium sorption capacity of chromium is clear. Meanwhile, the effect of $\mathrm{pH}$ on the lead equilibrium $C_{s}$ is minor. 


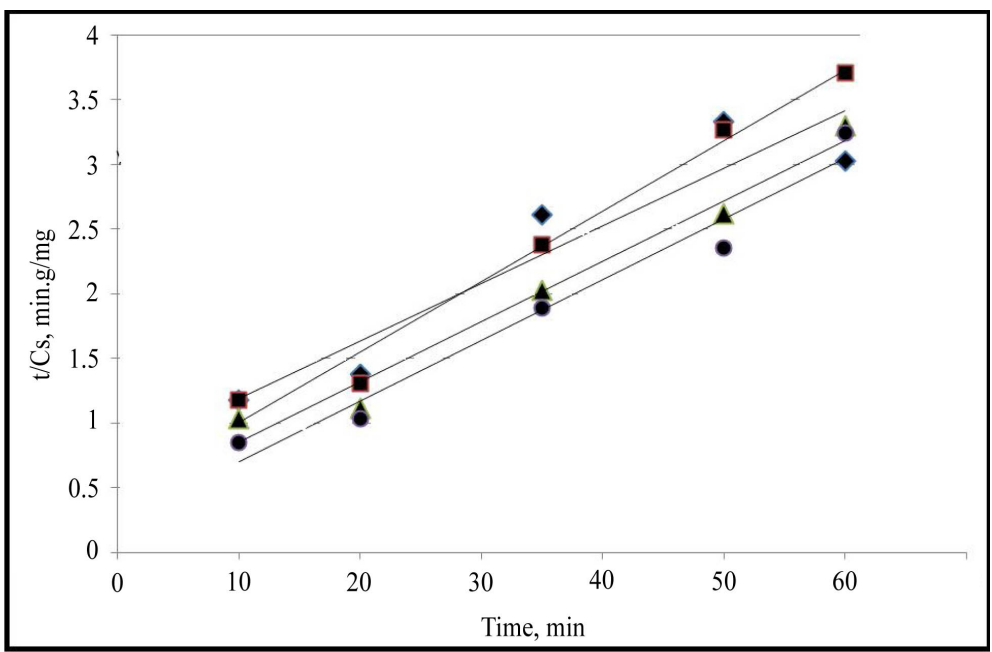

Figure 12. Lead adsorption kinetic plots following pseudo second order model at $\mathrm{pH}=\bullet, 3 ; \mathbf{\square}, 4.5 ; \boldsymbol{\Delta}, 6$ and $\bullet, 7.5$.

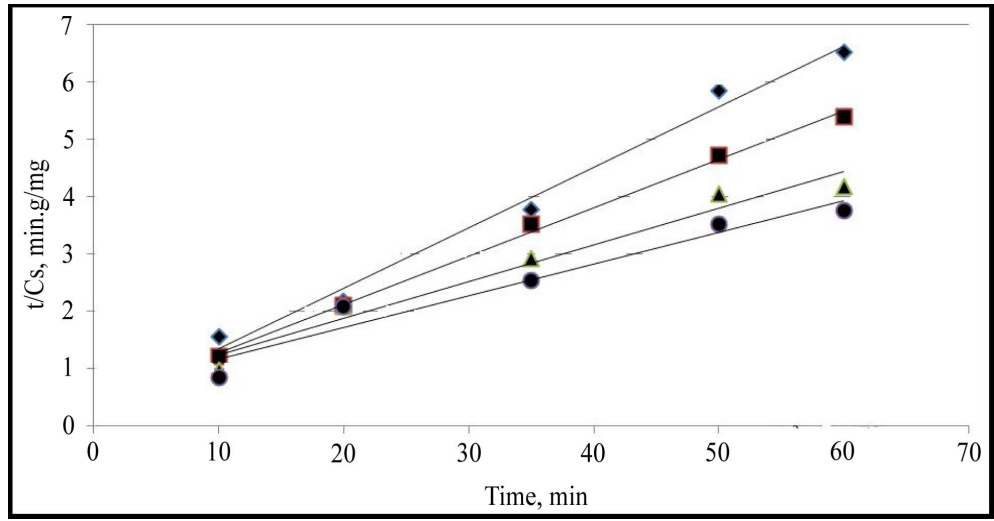

Figure 13. Chromium (III) adsorption kinetic plots following pseudo second order model at $\mathrm{pH}=\bullet, 3 ; \mathbf{-}, 4.5 ; \boldsymbol{\Delta}, 6$ and $\bullet, 7.5$.

Table 4. Evaluation of the adsorption kinetics of chromium and lead on monmorillonite.

\begin{tabular}{ccccc}
\hline \multirow{2}{*}{$\mathrm{pH}$} & \multicolumn{2}{c}{ Lead Adsorption } & \multicolumn{2}{c}{ Chromium Adsorption } \\
\cline { 2 - 5 } & $C_{\mathrm{s}}, \mathrm{mg} / \mathrm{g}$ & $\mathrm{K}, \mathrm{g} \cdot \mathrm{mg}^{-1} \cdot \mathrm{min}^{-1}$ & 9.52 & $\mathrm{~K}, \mathrm{~g} \cdot \mathrm{mg}^{-1} \cdot \mathrm{min}^{-1}$ \\
\hline 3 & 22.47 & 0.0026 & 11.85 & 0.0346 \\
6.5 & 18.35 & 0.0064 & 15.61 & 0.016 \\
7.5 & 21.46 & 0.0056 & 18.08 & 0.007 \\
\end{tabular}

\section{Conclusion}

Experimental design was used to establish the most favorite conditions for the removal of chromium and lead from water by adsorption on a certified Iraqi montmorillonite. Effective adsorption capacity of $21.46 \mathrm{mg} / \mathrm{g}$ for chromium was obtained within 40 - 50 in a neutral medium. The acid medium resulted in low adsorption which suggested a desorption process for the adsorbed chromium. Almost $100 \%$ removal efficiency could be obtained for lead from water by adsorption on Iraqi montmorillonite under slightly acidic to neutral medium. The equilibrium could be attained within 45 - 50 minutes. The most favorable conditions for simultaneous $\mathrm{Cr}$ and $\mathrm{Pb}$ might be $12.5 \mathrm{~g} / \mathrm{L}$ clay content and a $\mathrm{pH}$ of 7.5 within 30 minutes. The sorption results fit reasonably with the pseudosecond order kinetic model which also confirmed the $\mathrm{pH}$ dependence of chromium adsorption. 


\section{Acknowledgements}

This work is supported by the Institute of International Education-Scholar Rescue Fund. The author is grateful to the dean and staff of college of Science and Mathematics, Montclair State University, NJ, USA for hosting him during the scholarship, to Dr. D. Sarkar, for his permission to use lab facilities to carry out this work; to Dr. H. Su for her help in the statistical treatment of lead results and to Dr. P. Punamiya for the help in the ICP measurements.

\section{References}

[1] Kinder, C. (1997) Lead Contamination in Our Environment, Yale-New Haven Teachers Institute. http://www.yale.edu/ynhti/curriculum/units//7/97.07.05.x.html

[2] Chaves, C. (2006) Northeast Assistance \& Pollution Prevention News. Reducing Lead in the Environment, 16.

[3] Gürel, L., Altaş, L., and Büyükgüngör, H. (2005) Removal of Lead from Wastewater Using Emulsion Liquid Membrane Technique. Environmental Engineering Science, 22, 411-420. http://dx.doi.org/10.1089/ees.2005.22.411

[4] Gupta, V.K., Mohan, D. and Sharma, S. (1998) Removal of Lead from Wastewater Using Bagasse Fly Ash-A Sugar Industry Waste Material. Separation Science and Technology, 33, 1331-1343. http://dx.doi.org/10.1080/01496399808544986

[5] Al-Jlil, S.A. and Alsewailem, F.D. (2009) Saudi Arabian Clays for Lead Removal in Wastewater. Applied Clay Science, 42, 671-674. http://dx.doi.org/10.1016/j.clay.2008.03.012

[6] Ibrahim, K.M. and Akashah, T. (2004) Lead Removal from Wastewater Using Faujasite Tuff. Environmental Geology, 46, 865-870. http://dx.doi.org/10.1007/s00254-004-1074-4

[7] Esmaeili, A., Mesdaghinia, A. and Vazirinejad, R. (2005) Chromium (III) Removal and Recovery from Tannery Wastewater by Precipitation Process. American Journal of Applied Sciences, 2, 1471-1473. http://dx.doi.org/10.3844/ajassp.2005.1471.1473

[8] Kim, J. and Vipulanandan, C. (1997) Removal of Lead from Wastewater Using a Biosurfactant. University of Houston, Houston. http://cigmat.cive.uh.edu/content/conf exhib/02 poster/8.html

[9] Barbooti, M.M., Zablouk, M. and Al-Zubaidi, U.A. (2010) Recovery of Chromium from Waste Tanning Liquors by Magnesium Oxide. International Journal of Industrial Chemistry, 1, 29-38.

[10] Rengaraj, S., Joo, C.K., Kim, Y. and Yi, J. (2003) Kinetics of Removal of Chromium from Water and Electronic Process Wastewater by Ion Exchange Resins: 1200H, 1500H and IRN97H. Journal of Hazardous Materials, B102, 257275. http://dx.doi.org/10.1016/S0304-3894(03)00209-7

[11] Roque-Malherbe, R.M.A., Duconge, H.J.J., Del Valle, W. and Toledo, E. (2007) Lead, Copper, Cobalt and Nickel Removal from Water Solutions by Dynamic Ionic Exchange in LECA Zeolite Beds. International Journal of Environment and Pollution, 31, 292-303. http://dx.doi.org/10.1504/IJEP.2007.016497

[12] Faout, N., Brar, S.K., Verma, M., Tyagi, R.D., Blais, J.F. and Surampalli, R.Y. (2008) Trivalent Chromium Ion Adsorption on Various Types of Wastewater Sludge. Practice Periodical of Hazardous, Toxic, and Radioactive Waste Management, 12, 181-187. http://dx.doi.org/10.1061/(ASCE)1090-025X(2008)12:3(181)

[13] Mahvi, A.H., Naghipour, D., Vaezi, F. and Nazmara, S. (2005) Teawaste as an Adsorbent for Heavy Metal Removal from Industrial Wastewaters. American Journal of Applied Sciences, 2, 372-375. http://dx.doi.org/10.3844/ajassp.2005.372.375

[14] Abdel-Ghani, N.T., Hefny, M.G.A. and El-Chaghaby, F. (2007) Removal of Lead from Aqueous Solution Using Low Cost Abundantly Available Adsorbents. International Journal of Environmental Science \& Technology, 4, 67-73. http://dx.doi.org/10.1007/BF03325963

[15] Sharma, D.C. and Forster, C.F. (1994) A Preliminary Examination into the Adsorption of Hexavalent Chromium Using Low Cost Adsorbents. Bioresource Technology, 47, 257-264. http://dx.doi.org/10.1016/0960-8524(94)90189-9

[16] Weng, C.H., Lin, Y.T., Lin, T.Y. and Kao, C.M. (2007) Enhancement of Electrokinetic Remediation of Hyper-Cr(VI) Contaminated Clay by Zero-Valent Iron. Journal of Hazardous Materials, 149, 292-302. http://dx.doi.org/10.1016/j.jhazmat.2007.03.076

[17] Arfaoui, S., Frini-Srasra, N. and Srasra, E. (2008) Modelling of the Adsorption of the Chromium Ion by Modified Clays. Desalination, 222, 474-481.

[18] Ajmal, M., Roa, R.A.K. and Siddiqui, B.A. (1996) Studies on Removal and Recovery of Cr(VI) from Electroplating Waste. Water Research, 30, 1478-1482. http://dx.doi.org/10.1016/0043-1354(95)00301-0

[19] Owlad, M., Aroua, M.K., Ashri, W., Daud, W. and Baroutian, S. (2008) Removal of Hexavalent Chromium-Contami- 
nated Water and Wastewater: A Review. Water, Air, and Soil Pollution, 200, 59-77. http://dx.doi.org/10.1007/s11270-008-9893-7

[20] Miretzky, P., Saralegui, A. and Fernández Cirelli, A. (2006) Simultaneous Heavy Metal Removal Mechanism by Dead Macrophytes. Chemosphere, 62, 247-254. http://dx.doi.org/10.1016/j.chemosphere.2005.05.010

[21] Carmona, M.E.R., da Silva, M.A.P. and Ferreira Leite, S.G. (2005) Biosorption of Chromium Using Factorial Experimental Design. Process Biochemistry, 40, 779-788. http://dx.doi.org/10.1016/j.procbio.2004.02.024

[22] Barrado, E., Vega, M., Pardo, R., Ruipérez, M. and Medina, J. (1996) Application of the Taguchi Experimental Design to the Removal of Toxic Metals from Waste Waters by Precipitation as Magnetic Ferrites. Analytical Letters, 29, 613633. http://dx.doi.org/10.1080/00032719608000425

[23] Gaikwad, R.W., Sapkal, R.S. and Sapkal, V.S. (2010) Removal of Copper Ions from Acid Mine Drainage Wastewater Using Ion Exchange Technique: Factorial Design Analysis. Journal of Water Resource and Protection, 2, 984-989. http://dx.doi.org/10.4236/jwarp.2010.211117

[24] Lawson, J. (2009) Design and Analysis of Experiments with SAS. CRC Press, Boca Raton.

[25] Pandey, P.K., Sharma, S.K. and Sambi, S.S. (2010) Kinetics and Equilibrium Study of Chromium Adsorption on ZeoliteNax. International Journal of Environmental Science \& Technology, 7, 395-404. http://dx.doi.org/10.1007/BF03326149

[26] Wehrli, B., Ibric, S. and Stumm, W. (1990) Adsorption Kinetics of Vanadyl(IV) and Chromium (III) to Aluminum Oxide: Evidence for a Two-Step Mechanism. Colloids and Surfaces, 51, 77-88. http://dx.doi.org/10.1016/0166-6622(90)80133-O

[27] Sekar, M., Sakthi, V. and Rengaraj, S. (2004) Kinetics and Equilibrium Adsorption Study of Lead(II) onto Activated Carbon Prepared from Coconut Shell. Journal of Colloid and Interface Science, 279, 307-313. http://dx.doi.org/10.1016/j.jcis.2004.06.042

[28] Figueroa, R.A., Leonard, A. and MacKay, A.A. (2004) Modeling Tetracycline Antibiotic Sorption to Clays. Environmental Science \& Technology, 38, 476-483.

[29] Krishnan, K.A. and Anirudhan, T.S. (2003) Removal of Cadmium(II) from Aqueous Solutions by Steam-Activated Sulphurised Carbon Prepared from Sugar Cane Bagasse Pith: Kinetics and Equilibrium Studies. Water SA, 29, 147-156. http://dx.doi.org/10.4314/wsa.v29i2.4849

[30] Ho, Y.S., Ng, J.C.Y. and Mckay, G. (2000) Kinetics of Pollutant Sorption by Biosorbents: Review. Separation and Purification Methods, 29, 189-232.

[31] Demirbas, E., Kobya, M., Senturk, E. and Ozkan, T. (2004) Adsorption Kinetics for the Removal of Chromium (VI) from Aqueous Solutions on the Activated Carbons Prepared from Agricultural Wastes. Water SA, 30, 533-539. http://dx.doi.org/10.4314/wsa.v30i4.5106 